\title{
Modeling the accuracy of the manufacturing machine
}

\author{
Jozef Svetlík ${ }^{1}$, Juraj Kováč르, Patrícia Dudová ${ }^{3}$, Jozef Dobránsky ${ }^{4}$ and Michal Považan ${ }^{5}$ \\ \{jozef.svetlik@tuke.sk ${ }^{1}$,juraj.kovac@ @uke.sk ${ }^{2}$, patricia.dudova31@gmail.com ${ }^{3}$, \\ jozef.dobransky@tuke.sk ${ }^{4}$,powica@gmail.com ${ }^{5}$ \}
}

Faculty of Mechanical Engineering, Technical University of Košice, Letná 9, 04001

Košice, Slovakia ${ }^{1,2,3,5}$,

Faculty of Manufacturing Technologies with a seat in Prešov, Technical University of Košice, Letná 9, 04001 Košice, Slovakia ${ }^{4}$

\begin{abstract}
When designing production machines, it is necessary to reduce development costs to a minimum. However, the required quality of designs for new or upgraded production machines must be respected. Verification of prototype machine prototypes can be done faster, cheaper and often more accurate. The article analyzes the manufacturing precision of the CNC production machine - milling machines with three controlled axes. As a basis for precision modeling, we select the simplified numerical virtual model of the production machine and perform virtual machining on it. The inaccuracy of the production machine is calculated by analyzing the finite elements on the computer.
\end{abstract} model

Keywords: production machine, virtual prototyping, mathematical modeling, digital

\section{Introduction}

The use of computer support is a common process when designing machine tools using CAD programs with the possibility to use FEM analysis. The ever-increasing demands on the design of machine tools and machining processes, HSC machining requires not only standard calculations of dynamic, static and thermal properties, but it is necessary to deeper and take into account the processes that affect the properties and the resulting precision of the machine tools [1-5].

One of the options is virtual modeling of machine tools using the above-mentioned CAD programs. It is virtual machining on a virtual model of a machine tool modeled in a CAD program where its properties are tested on mathematical models. To perform the prototype activity we decided to use the PTC Creo Parametric CAD system. We have chosen this program because of the knowledge and experience we have acquired during work on other projects, the simplicity of the FEM analysis and its availability in the workplace. 


\section{Definition of the problem}

In the following research, we will consider a production machine having three driven axes, Fig. 1.

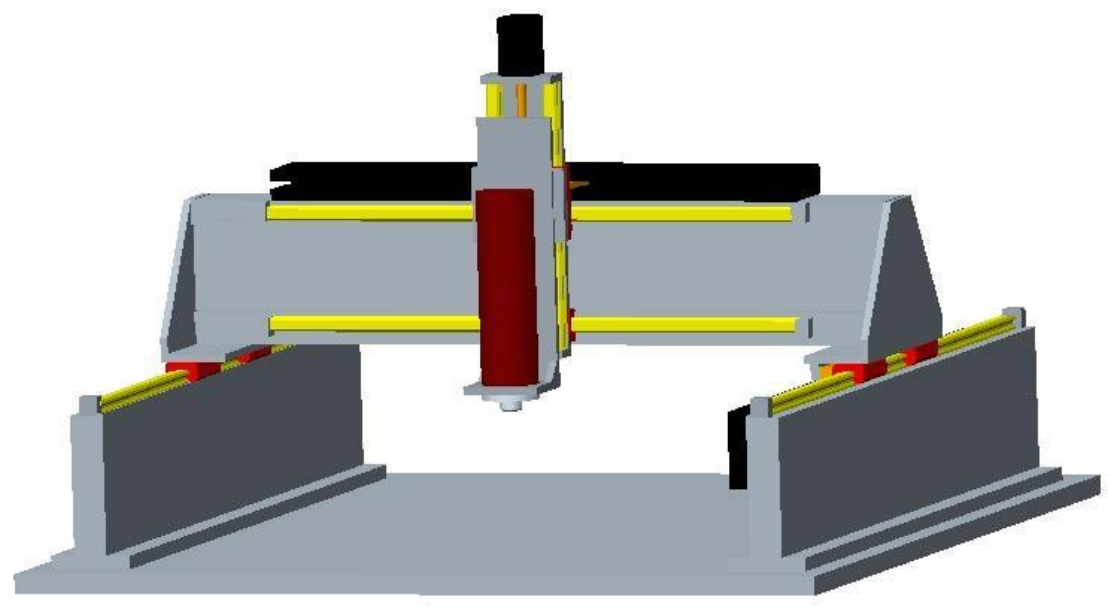

Fig. 1. Tri-axis cnc milling machine LMG2A-CB6-CC8 [7]

In the first step, we replace the machine with a mathematical model. Generally, it is best to make the calculation model simple. However, it has to meet the key features influencing its working precision. Subsequently, it is necessary to determine the trajectory equation of the tool in a coordinate system such as the workpiece / component and to determine the influence of inaccuracies bound to the individual nodes of particular machine tools for the overall machining accuracy. Finally, these effects have to be transformed into the workpiece contact area and superposed here.

\subsection{Making a mathematical model of a machine tool}

To analyze the accuracy of machining on a particular machining machine for a particular workpiece / component, it is necessary to replace the machine with an adequate mathematical model. As a rule, it is most appropriate for the computational model to be as simple as possible but to fulfill the key facts and features that impinge on its precision [1].

When examining work precision analysis of machine tools using their mathematical models, it is necessary to determine the tool trajectory equation in a coordinate system such as the workpiece / component and to determine the effects of inaccuracies bound to individual nodes of particular machine tools for overall machining accuracy. Finally, these effects have to be transformed into the workpiece contact / workpiece and then superposed [1].

Such an analysis should follow the steps, if necessary: 
- Determine the sequence of machine tool nodes - model bodies (movable and stationary) in the direction from the workpiece / component to the tool,

- Determine the coordinate systems of specific model bodies of the calculation model of the machine,

- Mathematically determine the mutual end positions of specific model bodies of the calculation model of the machine tool - column vectors $\left\{\mathbf{K}_{\mathrm{i}+1, \mathrm{i}}\right\}$,

- Mathematically determine the movements of specific model bodies of the calculation model of the machine,

- Mathematically determine the transformation vectors of the direct movements $\left\{\mathbf{T}_{\mathrm{i}+1, \mathrm{i}}\right.$ $(t)\}$ and the transformation matrices of the rotational movements $\left[\mathbf{R}_{\mathrm{i}+1, \mathrm{i}}(t)\right]$ of specific model bodies of the machining centre model,

- Mathematically define inaccuracies and deformations of individual model bodies of the machining centre model and their time changes during machining [1].

When constructing a calculation model of a machine tool to be subjected to an accuracy analysis, it is based on the composition of its carrier system. Therefore, it is sufficient for us to replace the individual nodes of the machine's support system with bodies that will have a simplified shape. However, their properties against the original node will be retained.

\subsection{The concept of the project}

The selected modeling object is a three axis milling machine with a vertical axis of machining with the gantry by arranging the structure [6]. The individual milling bodies are:

T1 - bed,

T2 - crossbar,

T3 - support,

T4 - spindle with spindle,

T5 - spindle.

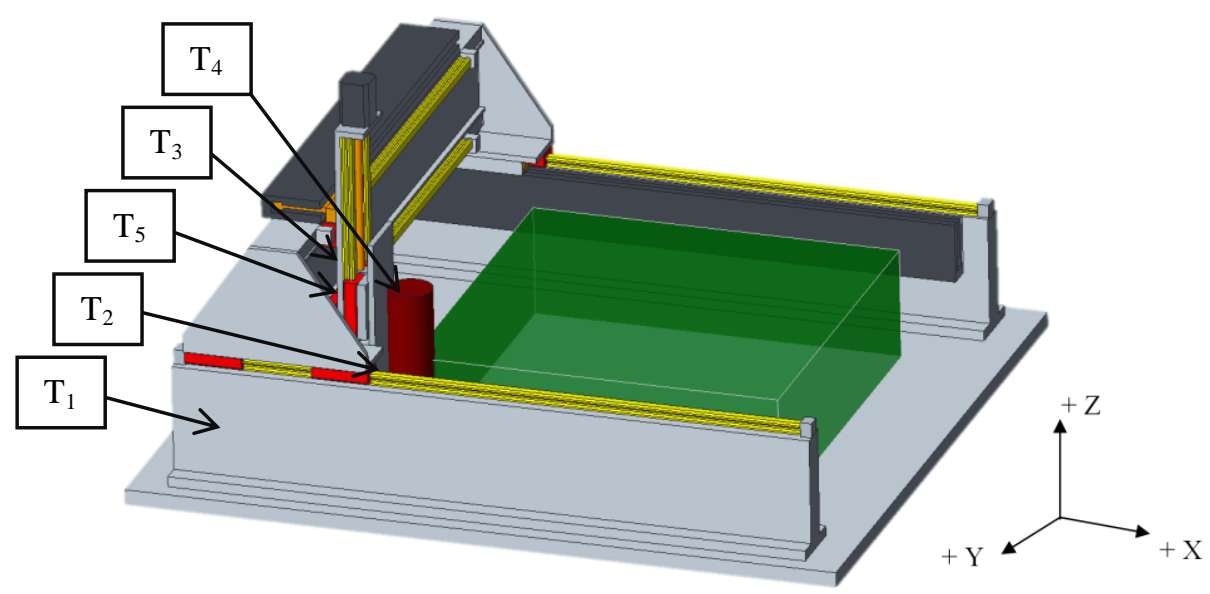

Fig. 2. Simplified model of a 3-axis machining center LMG2A-CB6-CC8 [3] 


\section{Digital model of the machining center and ideal workpiece}

The calculation model is available to determine the basic dimensions of the machining center and to display the coordinate systems of each model body. For model bodies $T_{1}$ to $T_{5}$ transformation matrices of rotational motion, transformation vectors of direct motion, and initial position vectors for the next body were determined. E.g. The model body $T_{l}$, which is the bed, does not move any moves relative to the stationary workpiece $T_{0}$. The workpiece is clamped in the plane $X_{I} Y_{I}$ so that its lower plane and plane of the bed are identified.

For the $T_{1}$ to $T_{5}$ model bodies, the transformation matrices of the rotational movements, the forward motion transformation vectors, and the starting position vectors for the next body will be determined at the following points. The order in which we perform these tasks has been chosen from the spindle to the machine bed $\left(T_{5}\right.$ to $\left.T_{1}\right)$.

\subsection{Detailed calculation model of the bed}

The values of the individual design dimensions are as follows: $\mathrm{d}_{1}=65 \mathrm{~mm}, \mathrm{e}_{1}=95 \mathrm{~mm}$, $\mathrm{g}_{1}=40 \mathrm{~mm}, \mathrm{~h}=77 \mathrm{~mm}, \mathrm{j}_{1}=10,7 \mathrm{~mm}$. Dimension $\mathrm{v}_{\mathrm{v}}$ Represents the height of the line resulting from the construction of the machine $(22,7 \mathrm{~mm})$ and the dimension $\mathrm{B}_{\text {omax }}$ is the maximum workpiece width that can be machined on the machine.

The rotary motion transformation matrix holds true:

$$
\left[\mathrm{R}_{10}\right]=\left[\mathrm{R}_{10}(\mathrm{t})\right]=[\mathrm{E}]
$$

Transformation vector of direct motion will be:

$$
\left\{\mathrm{T}_{10}\right\}=\left\{\mathrm{T}_{10}(\mathrm{t})\right\}=\{0\}
$$

The initial position vector has a shape:

$$
\left\{\mathrm{K}_{10}\right\}=\left\{-\left(\mathrm{e}_{1}+\mathrm{h} / 2+\mathrm{B}_{\mathrm{omax}} / 2\right)-\left(\mathrm{d}_{1} / 2+\mathrm{v}_{\mathrm{v}}+\mathrm{g}_{1}+\mathrm{j}_{4}+\mathrm{j}_{5}+\mathrm{j}_{1}\right) 0\right\} \mathrm{T}
$$

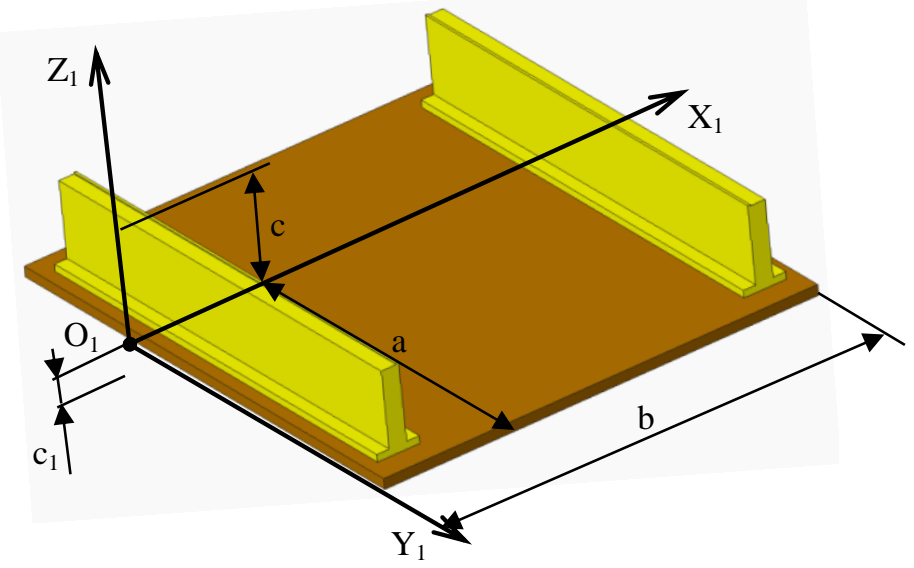

Fig. 3. Detailed calculation model of the bed of the milling machine [3] 


\subsection{Detailed Spindle Calculation Model}

The values of the individual design dimensions are as follows: $d_{1}=65 \mathrm{~mm}, \mathrm{e}_{1}=95 \mathrm{~mm}$, $\mathrm{g}_{1}=40 \mathrm{~mm}, \mathrm{~h}=77 \mathrm{~mm}, \mathrm{j}_{1}=10,7 \mathrm{~mm}$. The dimension vv represents the track height resulting from the machine design $(22,7 \mathrm{~mm})$ and the $\mathrm{B}_{\text {omax }}$ dimension is the maximum workpiece width that can be machined on the machine. The rotary motion transformation mat has a shape at any time:

$$
\left[\mathrm{R}_{54}\right]=\left[\mathrm{R}_{54}(\mathrm{t})\right]=\left[\begin{array}{ccc}
\cos \gamma 5(t) & -\sin \gamma 5(t) & 0 \\
\sin \gamma 5(t) & \cos \gamma 5(t) & 0 \\
0 & 0 & 1
\end{array}\right]
$$

Where instantaneous values of angle $\gamma 5(t)$ at any time $t$ can be calculated based on the spindle speed $\mathrm{n}_{\mathrm{v}}$ and thus:

$$
\gamma 5(t)=\frac{\pi \cdot n v \cdot t}{30} \quad(\mathrm{rad})
$$

For our machine tool, we think that virtual machining will consider the spindle as immobile. The rotary motion transformation matrix will therefore be unitary:

$$
\left[\mathrm{R}_{54}\right]=\left[\mathrm{R}_{54}(\mathrm{t})\right]=[\mathrm{E}]
$$

We also do not expect a combination of spindle rotation and rotation, which implies that the transformation vector for:

$$
\left\{\mathrm{T}_{54}\right\}=\left\{\mathrm{T}_{54}(\mathrm{t})\right\}=\{0\}
$$

The figure shows that the initial position of the spindle relative to the body $\mathrm{T}_{4}$ will be:

$$
\left\{\mathrm{K}_{54}\right\}=\{0,0,-\mathrm{o}\} \mathrm{T}
$$

Where the value of the constructional dimension o is 0 . We also do not expect a combination of spindle rotation and rotation, which implies that the transformation vector for the direct motion will:

$$
\left\{\mathrm{T}_{54}\right\}=\left\{\mathrm{T}_{54}(\mathrm{t})\right\}=\{0\}
$$

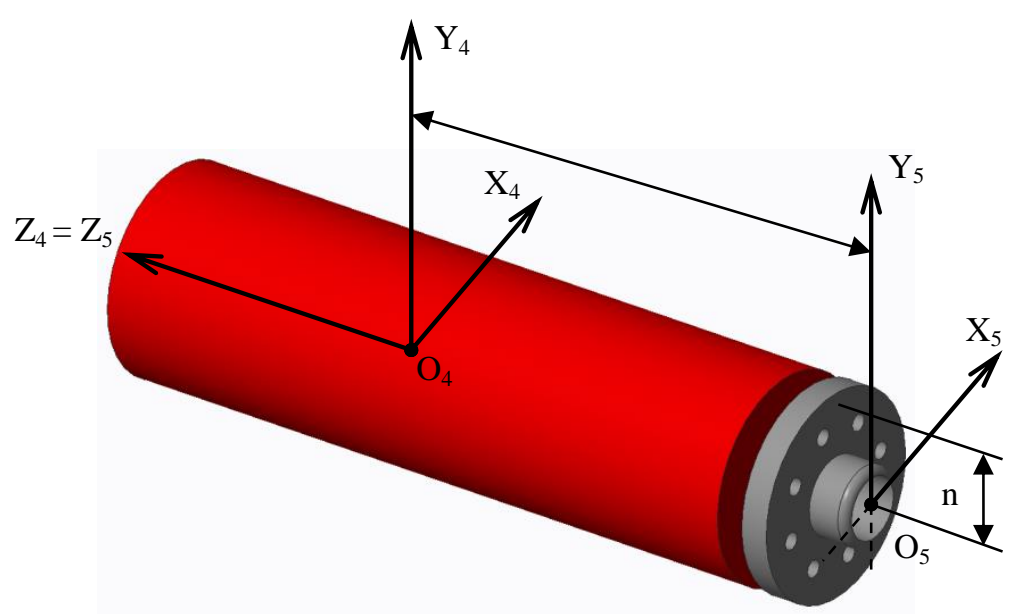

Fig. 4. Detailed spindle calculation model of the milling machine [3] 


\subsection{Detailed computational model of the support}

In the virtual model, the body $\mathrm{T}_{3}$, is the one that moves directly towards the transverse axis in the direction of the $\mathrm{X}_{2}$ axis. In the mathematical model, it performs this movement along with the previous $\mathrm{T}_{4}$ and $\mathrm{T}_{5}$ bodies. The rotary motion transformation matrix will be:

$$
\left[\mathbf{R}_{32}\right]=\left[\mathbf{R}_{32}(\mathrm{t})\right]=[\mathbf{E}]
$$

Transformation vector of direct motion will be:

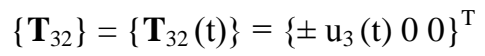

Where $u_{3}(t)$ is the value of the instantaneous path that the model body $T_{3}$ runs at a given time $t$, in the direction of the $\mathrm{X}_{2}$ axis. We determine it by using the direct feed on the milling cutter $f_{x}$ and thus:

$$
\mathrm{u}_{3}(\mathrm{t})=\mathrm{f}_{\mathrm{x}} \cdot \mathrm{z}_{\mathrm{f}} \cdot \mathrm{n}_{\mathrm{v}} \cdot \frac{t[s]}{60}=0,045 \cdot 4.5730 \cdot \frac{t}{60}=17,19 \mathrm{t}(\mathrm{mm})
$$

We assign the mark to the resulting value $\mathrm{u}_{3}(\mathrm{t})$ according to the direction of movement of the support such that when it moves in the left-hand direction to the right, then the support performs a relative movement in the positive sense of the axis $X_{2}$ and the value $u_{3}(t)>0$ and thus plus (+). Otherwise, we use the minus sign (-). The co-ordinates of the starting position vector are represented as follows: $\mathrm{x}_{03} \in\left\langle x_{\min } ; x_{\max }\right\rangle$.

$$
\begin{gathered}
\mathrm{y}_{03}=\mathrm{d}_{1} / 2+\mathrm{v}_{\mathrm{v}}, \mathrm{z}_{03}=\mathrm{f} / 2-\mathrm{i}_{1} \\
\mathrm{x}_{\min }=\mathrm{e}_{1}+\mathrm{h} / 2, \mathrm{x}_{\max }=\mathrm{x}_{\min }+\mathrm{B}_{\text {omax }}
\end{gathered}
$$

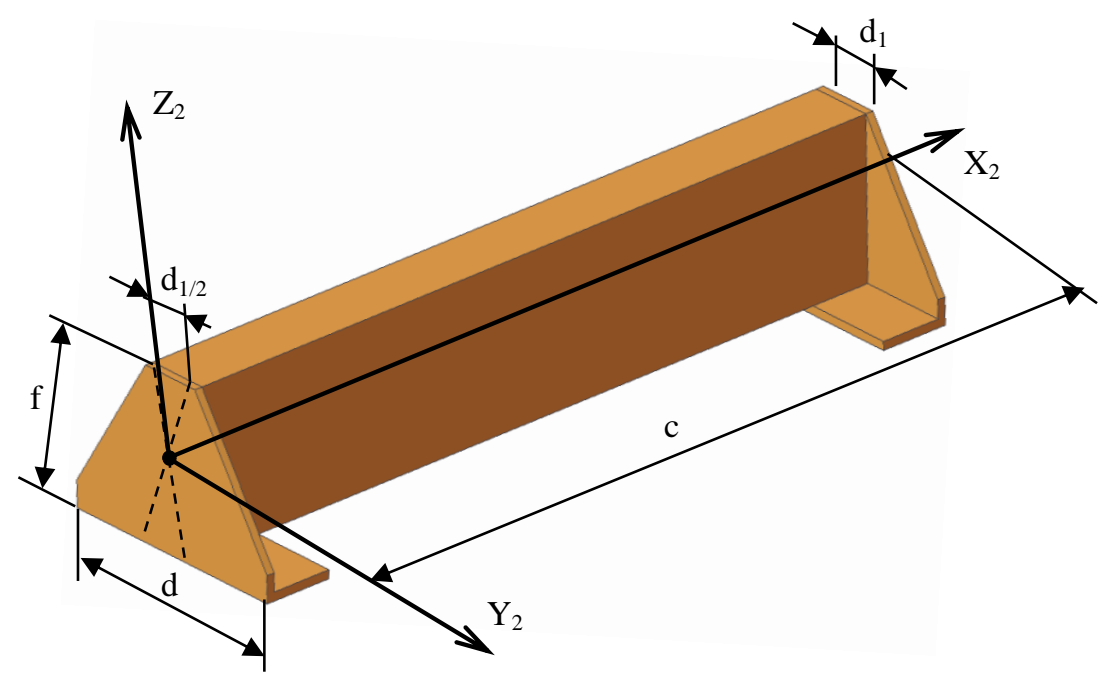

Fig. 5. Detailed support calculation model of the milling machine [3] 


\section{Conclusion}

In virtual machining, it is not possible to numerically simulate the whole model as a numerical simulation and it is therefore sufficient to perform a numerical simulation analysis at specified points. The track running along the rail with the support, slide, spindle, spindle and tool at time $\mathrm{t}$ will be $2000 \mathrm{~mm}$. The entire process of virtual machining will take on the given machining parameters $t \approx 116,346 \mathrm{~s}$, according to the established relation, it is possible to calculate the machining time of one section $k=50 \mathrm{~mm}$ and therefore $t_{\Delta} \approx 2,909 \mathrm{~s}$.

From the calculated, measured and assembled data, it can be stated that our machining center would need some design adjustments to reduce inaccuracies, especially in machining directions $\mathrm{Y}$ and $\mathrm{Z}$. The biggest inaccuracies in these directions were for the direction $\mathrm{Z}=$ $0,636 \mathrm{~mm}$ and for the direction $\mathrm{Y}=0,879 \mathrm{~mm}$ with parallel milling. For counterbore milling it was for axes $\mathrm{Z}=0,666 \mathrm{~mm}$ and for axis $\mathrm{Y}=1,379 \mathrm{~mm}$. For direction $\mathrm{X}$, the resulting inaccuracies resulted in a fairly good level with parallel milling $X=0,066 \mathrm{~mm}$ and countermilling $X=0,130 \mathrm{~mm}$.

Acknowledgments. The article was supported by grant projects: VEGA 1/0437/17 Research and development of rotary module with an unlimited degree rotation, KEGA 039TUKE4/2016 Creation of virtual laboratories based on WEB technologies to support the educational process in the field of Manufacturing Technology, VEGA 1/124/15 Research and development of advanced methods for virtual prototyping of manufacturing machines and APVV-15-0149 Research of new measuring methods of machine condition.

\section{References}

[1] Demeč, P., Svetlík, J., Semjon, J.: Virtuálne prototypovnie obrábacích strojov z hl'adiska dynamiky procesov obrábania, 1. vyd. Košice, SjF TU, 2011, 182 s. ISBN 978-80-553-0815-9.

[2] Marinčin, J. N.: Využitie technológií virtuálnej reality pri navrhovaní výrobných systémov [online] http://fstroj.utc.sk/journal/sk/43/43.htm

[3] Piliš, A.: Numerické modelovanie a analýza presnosti trojosého obrábacieho centra. SjF Technická univerzita v Košiciach. Diplomová práca 2016.

[4] Keka, B.: Analýza metódou konečných prvkov je integrovaná do CAD systémov. In MM Spectrum, 2005/6, 48 s. [online] http://www.mmspektrum.com/clanek/analyza-metodou-konecnych-prvku-jeintegrovana-do-cad-systemu.html

[5] Demeč, P.: Presnost' obrábacích strojov a jej matematické modelovanie, 2001, Vienala Košice, $146 \mathrm{~s}$. ISBN 80-7099-620-X.

[6] Demeč, P.: Výrobná technika - základy stavby. 1. vyd. Košice : TU, 2013. 296 s. ISBN 978-80-5531615-4.

[7] HIWIN, Motion control \& Systems [on-line] http://www.hiwin.cz/cz/produkty/polohovacisystemy/gantry-systemy/146_gantry-system-lmg2a-cb6-cc8 